\title{
V. Voiculescu. \\ Contextul biografic și mitul personal la începuturi
}

\author{
Drd. Aura-Valentina CĂȘUNEANU-PANAITIU \\ Universitatea „Dunărea de Jos” din Galați
}

\begin{abstract}
This paper aims at mapping the symbols present in Vasile Voiculescu's poetry, with a view to discover the obsessive, recurrent images, as well as the relations that can be established between these images. Aiming to analyse them with the tools of psychocriticism, I have chosen poems included in the volume Pârgă [Ripeness] (1921): Apus de soare (Sundown), Sunt peșteri (There are caves), La răscruce (At the crossroads), Destinul (Fate), Vânătoare Veche (Old Hunt). With consideration to the existing studies, an attempt will be made at reconstituting the imaginary universe of the author Vasile Voiculescu: one supported by the imaginary revealed in the poetry published during his lifetime, and the other, by that in the poems published posthumously.
\end{abstract}

Keywords: image mapping, recurrence, symbols

„Dictaturile se nasc și mor. Sub ele, literaturile, culturile se chinuie, își contorsionează discursul, dar supraviețuiesc". [Simuț, 2017:15]

Urmărind mișcarea formelor literare în spațiul cultural românesc, discursul literar este abordat dintr-o perspectivă trans și interdisciplinară, după criteriul estetic, istoric și politic. Captiv unui regim dictatorial, autorul V.Voiculescu este poziționat de Ion Simuț în categoria evazioniștii, deoarece literatura sa nu este expresia directă a politicului și nu se conformează rigorilor regimului totalitar, nefiind solidară cu acesta și fiind considerată artă degenerată din cauza limbajului deviat. Urmărind raportul dintre estetic și etic și având în vedere criteriul cronologic istoric și politic, Ion Simuț propune patru tipuri de literaturi: 1. Oportunistă sau conformistă, care cuprinde creația scriitorilor ce au făcut pact cu ideologia regimului politic, ilustrând-o în proză, poezie, teatru sub formă de propagandă, o literatură care încalcă principiul estetic, fiind doar expresia dorinței de afirmare a scriitorilor care fac un compromis politic și ideologic. Rezultatul acestui joc estetico-politic este uniformizarea talentelor, chiar distrugerea celor mari și susținerea celor mici, cum nota Cezslaw Milosz; 
2. Evazionistă, care nu se adaptează politicului, dar care se definește prin formalism estetic, „arma periculoasă” 158 [Ion Simuț, 2017:351] împotriva regimului totalitar. Cei care nu intră în rânduri, nu adoptă un limbaj ideologic oficial, se salvează din punct de vedere moral scriind o literatură pentru sertar cum este și cazul lui V.Voiculescu a cărui operă scrisă între anii 1945-1963 va fi publicată postum.

3. Literatură subversivă- ,,o deviație mascată în metafore și parabole”159[ Ion Simuţ, 2017:50], într-un cod lingvistic secret, între scriitor și cititor, descifrat prin intermediul aceleeași experiențe sociale, și care reușește să treacă de cenzura regimului ceaușist. 4. Cea disidentă și literatura exilului-în această categorie se află scriitorii care manifestă în mod voit și asumat opoziția față de regimul comunist și care vor fi sancționați prin imposibilitatea afirmării în țară. Scriitorii protestatari sfârșesc la închisoare în epoca lui Gh. Gheorghiu Dej, și în exil, în epoca lui Ceaușescu. Autorul reușește să așeze pe fundalul Istoriei postbelice patru direcții literare care au dezvăluit dramele scriitorilor români într-un regim represiv.

Vasile Voiculescu este unul dintre scriitorii care au suferit, fiind condamnat la închisoare pentru uneltire împotriva regimului și pentru că a citit poezii religioase la întâlnirile de la Rugul Aprins, întâlniri ce aveau loc la Mănăstirea Antim. Universul imaginar al autorului se construiește din structuri antitetice, din simboluri ascensionale, din imagini Arhetipale, din frământări interioare și constrângeri politice, din sincronizarea operei atât cu modelul tradițional cât și cu cel universal. Dincolo de fluctuațiile istoriei literare, de contextul istoric, politic, cultural, se pot delimita mai multe profiluri ale autorului, unul format în timp, pe parcursul anilor, de la vol. de debut -1916, până în 1944, perioada în care vorbim de poeziile antume, și cel de-al doilea profil, conturat între anii 1950-1964, după publicarea postumă a poeziilor scrise în perioada menționată. Sub lupă psihocritică vom încerca o cartografiere a simbolurilor care apar în poezia lui V. Voiculescu pentru a descoperi harta imaginilor obsedante și recurente precum și raporturile ce se pot stabili între aceste imagini. Mauron propune o investigare a inconștientului scriitorului pornind de la afecte argumentând de ce acuză interpretarea psihanalitică de monotonie și reducționism, deoarece opera literară nu trebuie rezumată la dorințele refulate în anii copilăriei, la complexele despre care vorbește Freud și care susține că imaginația are funcție restauratoare deoarece permite, pe cale 
imaginativă, satisfacerea dorințelor inconștiente, prin fantezie ca activitate spirituală. Metoda propusă de Mauron ordonează Cuvintele în rețele de asociații afective, rețele care sunt autonome în raport cu structurile conștiente, și manifestă o fantasmă obsedantă ce reflectă starea afectivă caracterizată de frecvența și durata unei emoții. Astfel, surprindem manifestarea eului profund, descoperind imaginile obsedante, rețeaua de asociații produse involuntar, având caracter fix, repetitiv, independent. Metoda liberei asociații promovată de psihanaliză este înlocuită, în demersul psihocritic, de suprapunerea textelor. Receptarea psihocritică a poeziei lui V. Voiculescu presupune căutarea și descopeprirea acelor asociații de idei involuntare sub structurile conștiente ale textului.

Am ales spre analiză psihocritică următoarele texte care fac parte din volumul Pârgă (1921):

Pârgă, Apus de soare, Sunt peșteri, La răscruce, Destinul, Vânătoare veche.

Textul Pârgă dezvoltă imaginea poetului care trudește și suferă până când ajunge la maturitatea actului poetic, rezultatul fiind unul satisfăcător prin recunoașterea și aprecierea urmașilor, a cititorilor. Metafora pomului zăbavnic care așteaptă pârguirea rodului ilustrează nădejdea acestuia în versurile: Am fost un pom zăbavnic...,târziu am răsărit.../ Nu m-au cruțat nici grindini, nici secetăndelungă,/Mi-s crengile sucite și cresc pipernicit/ Iar biată rădăcină, căznindu-se sajung/ In lutul gras și reavăn, prin pietrea-sfredelit. Deși pare simplă, această metaforă ascunde o stare afectivă profundă prin care pot fi destăinuite anumite procese inconștiente. având în vedere nuanțele afective, cuvintele fiind alese și înrudite conștient. Încărcătura afectivă care însoțește fantasmă provoacă o stare de melancolie.

Rețeaua asociativă grupează următoarele idei, care la rândul lor sunt întruchipate de cuvinte simbol, alese și înrudite conștient.

suferință: zăbavnic- căznind-sfredelit-grindini-secetă;

triumf/izbândă: rodesc-suind-culegători;

preschimbare/metamorfoză: amara mâzgă- se-ndulcește -plăsmuieștepârguiește;

timpul: târziu-astăzi-vremuri

moartea: lutul-încovoiat

Rețeaua descoperită nu trebuie să se confunde cu metafora în jurul căreia se organizează poemul. Dovedindu-i caracterul obsesiv și involuntar, demonstrăm că este rezultatul proceselor inconștiente ale autorului.

În poezia Sunt peșteri „,Tu nu uita că sunt în tine peșteri.../Un pas, o șoaptă, numai un suspin,/ Sporesc acolo-n mii și mii de creșteri,/Se-ngroașă-n hăuri, se izbesc 
și vin/ Să zguduie pereții arși de lavă., rețeaua asociativă se manifestă prin următoarele idei și imagini:

Suferință: $\quad$ suspin-zguduie-tună-oftat-urlet

Izbândă: $\quad$ slavă-sus-ceruri

Metamorfoză: zvonul-steiul detunat-bolți năruite

Moarte: peșteră-pământ-năruie-sparge-tainiță

În ambele texte sunt ilustrate ideea morții și a triumfului prin suferință. Subiectul celor două contrarii este același: existența interioară a eului poetic, sufletul său mistuit de focul deznădejdii redat prin metaforele care se suprapun foc-lumina soarelui ce pârjolește și focul-lava ce arde la rându-i sufletul. Rețeaua rămâne constantă în ciuda faptului că circumstanțele se schimbă. Dacă pomul, ca element al spațiului exterior devine simbolul verticalității conform teoriei lui G. Durant, ascensiunii, a circumscrierii în veșnicie prin suferință, peștera definește spațiul închis, interior, supus suferinței, spaimei. Trupul -materia și sufletul-spiritul sunt cele două aspecte inseparabile ale existenței poetului.

În poemul La răscruce, sufletul este definit metaforic cale pustie, întretăiată de drumuri sălbatice, străine, eul poetic privește dezorientat, neștiind pe care dintre ele să apuce. Crucile mute sunt tovarășii sufletului său „cruci fără de

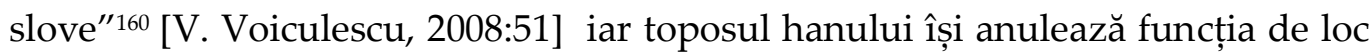
de popas odihnitor, devenind dimpotrivă, pustiu, prefigurând ideea morții. Poetul contemplă dincolo de pereții pustii, la răspântiile sufletului, șovăind la „o furcă de drumuri neumblate". În ciuda schimbării datelor exterioare (loc, timp, circumstanțe) rețeaua asociativă rămâne constantă: suferință, timp, moarte.

Cuvintele „, zăbavnic", ,"căznind", ,,suspin” susțin obsesia scrierii operei, iar în celelalte două texte se identifică obsesia unei drame solitare. Semnificația unei imagini obsedante este profundă. Metamorfoza om-pom,om-peșteră, omdrum/cale pustie definește obsesia scindării eului poetic. Textele descriu starea de neliniște, fiecare dezvoltând metafora scindării eului poetic.

Poemul Destinul devoalează tema trecerii timpului, a vieții, urmărind prefacerile datului existențial. Destinul, imaginat ca un orb, se târâie, dibuind prin întuneric să iasă la lumină. După o lungă călătorie anevoioasă, chinuit de piedicile peșterilor vieții sale, el apare în ipostaza Bătrânului -Orb cu mâinile grele la a căror atingere pietrele tresar speriate. Ideea spațiului exterior ostil este sugerată de metafora pereții reci, iar suferința se accentuează prin coborârea în propria-i ființă, motivul dublului spiritual simbolizând căutarea și reflectarea 
materialului în imaterial. Refuzând condiția umană, poetul evadează prin intermediul visului în conștiința existenței sale spirituale, coborârea însemnând redescoperirea sufletului, calea către atingerea absolutului, atitudinea față de moarte și față de timp fiind redefinită prin raportarea la eros- cronos-thanatos. Circumstanțele acestei călătorii sunt altele față de cele din poeziile analizate anterior pentru că scările de blocuri răsturnate sunt urcate în sens invers. În labirintul ființei orientarea este dificilă, deoarece imaginea lui e dublată la nesfârșit între vâltoarea apelor și năruirile bolților care-l doboară. Versurile conclusive, cu cât înaintează în lumină și tumult/ cu-atâta întunericul îi copleșește ochii tot mai mult, sugerează mâhnirea ființei umane al cărei Destin târăște, în lanțuri, Viitorul.

În Apus de Soare, suprapunerea va plasa coborând peste hodină, Seară, infocatul Soare peste nemărginitul iezer de lumină conchidem că există o legătură între peisajul nocturn și caii/telegarii, cu trupul flăcări și coamele vâlvoi ce va determina ideea de suferință asociată cu imaginea Soarelui care se revarsă în calea Serii, ca o apă. În Vânătoare Veche, Femeia este arta, vânătoarea. Ele sunt totuna pentru poetul care descrie momentul plecării la o partidă de vânătoare, inspirația, metamorfoza creției. Această idee reflectă izbânda zbuciumului lăuntric iar rețeaua de asociații formată în jurul ideii de moarte este reprezentată de cuvintele simbol suspin, peșteră,pământ,

Analizând rețeaua de imagini asociative ideilor, s-a descoperit obsesia autorului pentru trecerea timpului. Acest ecou inconștient determină scindarea ființei, drama individului în fața imposibilității recuperării timpului primordial, dezvoltând mitul personal al deznădejdii, al anxietății ceea ce-i provoacă suferință. Asociind cronologia creației voiculesciene cu etapele construcției spirituale de sine, alăturând predispoziția sa spre dimensiunea sacră a existenței și experiențele de tip Rugul Aprins, Vasile Voiculescu respinge cotidianul citadin în detrimentul unui spațiu compensator ce-i oferă iluzia unei seninătăți contemplative prin desfășurarea activității de medic militar în Bârlad, în 1917, când în ciuda problemelor de sănătate (bolnav de tifos) îi îngrijește pe bolnavi. Discursul liric devine spațiul prielnic de manifestare a modalităților poetice de restabilire a unui echilibru pierdut. Suprapunerea textelor face să apară o traumă (scindarea eului, suferința, izolarea, singurătatea, moartea) care se repetă obsesiv și involuntar. Imaginea omului suferind dovedește că ea obsedează imaginația autorului și constituie o fantasmă. În ceea ce privește încărcătura sa afectivă, ea definește o stare de nesiguranță, de anxietate, iar în aceste poezii se dezvăluie adevărata structură sufletească a poetului: natura telurică înfiorată de puternice aspirații spirituale care conturează timid mitul 
personal al poetului V. Voiculescu la începuturile creației sale artistice desfășurată concomitent cu cea a carierei de medic.

\section{Bibliografie}

1. Vasile Voiculescu - Corpus de texte Voiculescu, Vasile, Opera literară. Poezia, Editura Cartex 2000, Bucureşti, 2004.

2. Voiculescu, Vasile, Poezii. Antologie, Jurnalul Național, București,2011.

Receptarea critică a poeziei lui V. Voiculescu

2. Studii de critică literară.

Al. Piru, Istoria literaturii române de la început până azi, Editura Univers, București, 1981;

Apetroaie, Ion, V. Voiculescu - studiu monografic, Editura Minerva, Bucureşti, 1975;

Braga, Mircea, $V$. Voiculescu in orizontul tradiționalismului, Editura Minerva, Bucureşti, 1984;

Grăsoiu, Liviu, Poezia lui Vasile Voiculescu, Editura Dacia, Cluj-Napoca, 1977;

Ilincar, Valerica, Vasile Voiculescu-de la geografia literară la geografia spirituală, Editura Solness, Timișoara, 2009;

Lovinescu, E., Scrieri, vol. 6: Istoria literaturii române contemporane 1900 - 1937, ediţie de Eugen Simion, Editura Minerva, Bucureşti, 1975;

Lovinescu, Eugen, Istoria literaturii române contemporane, vol.1, editura Minerva, București, 1973;

Manolescu, Nicolae, Istoria critică a literaturii române. 5 secole de literatură, Editura Paralela 45, Piteşti, 2008;

Mauron, Charles, De la metaforele obsedante la mitul personal, traducere din limba franceză de Ioana Bot, ed. Dacia, Cluj-Napoca, 2001;

Papadima, Ovidiu , Peisajul interior în poezia lui V. Voiculescu (Scriitorii şi înţelesurile vieții, Bucureşti, Editura Minerva, 1971;

Pascu, Eugenia, Vasile Voiculescu-poet și prozator, Editura Timpul, Reșița, 2002;

Popescu Florentin, Viața lui V. Voiculescu, Ediția a doua revăzută și adăugită, Editura Vestala, București, 2008;

Simuț, Ion, Literaturile române postbelice, Editura Școala Ardeleană, ClujNapoca, 2017

Voiculescu, V., Integrala operei poetice, ediție de Roxana Sorescu, Bucureşti, Editura Anastasia, 1999. 